\title{
KEY3 Laser Treatment Applications in Oral and Maxillofacial Surgery
}

\author{
Fardad Shakibaie and Laurence J Walsh* \\ Department of Dentistry, The University of Queensland, Australia
}

Submission: December 11, 2017; Published: December 20, 2017

*Corresponding author: LJ Walsh, School of Dentistry, The University of Queensland, UQ Oral Health Centre, 288 Herston Road, Herston QLD 4006, Australia, Tel: 61733658160; Fax: 61733658199; Email: l.walsh@uq.edu.au

\begin{abstract}
The KEY3 is an advanced Er:YAGlaser system with an inbuilt fluorescence diagnostic system. The laser can be operated manually or with the aid of fluorescence guidance. The latter can be used for "autopilot" guidance of laser surgical procedures. The laser wavelength of $2.94 \mu \mathrm{m}$ is effective for ablating soft tissues as well as bone and tooth structure.
\end{abstract}

Keywords: Clinical oral surgery; Er:YAG ablation; KEY3 laser system; Surgical laser applications

\section{Mini Review}

The KEY3 Laser (KaVo, Biberach, Germany) is an Er:YAG laser system with a wide range of clinical applications in dentistry [1-3]. The laser incorporates an Indium Gallium Arsenide Phosphate visible red diode laser which emits at $655 \mathrm{~nm}$, as an excitation source for fluorescence diagnostics. This is based on the same laser wavelength being used in stand-alone diagnostic devices [4-9]. Fluorescence information can be used to guide the clinician in detecting sites of bacterial infection and disease $[10,11]$, including on the surfaces of teeth $[12,13]$. The feedback allows selective ablation of target surfaces once a threshold has been passed [1,14]. In effect, the fluorescence serves as an autopilot to control the firing of ablative pulses of Er:YAG laser energy [15].

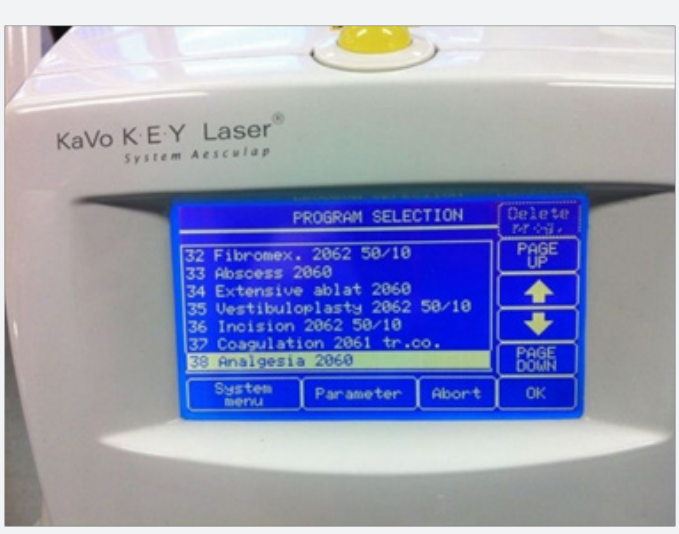

Figure 1: Program selection for surgical applications.
The laser wavelength of $2.94 \mu \mathrm{m}$ gives effective ablation of soft tissues as well as bone and tooth structure. A range of surgical procedures have pre-set parameters, and the clinician chooses from several on screen menus (Figure 1). Listed applications include apicectomy, frenectomy, exposure of the sulcus, drying of the sulcus or stemming of blood flow, implant exposure, treatment of herpes or aphthous ulcers, fibroma excision, incision of abscesses, treatment of oral mucosal diseases, vestibuloplasty, incisions and excisions, removal of impacted third molars, removal of exostoses, and remodelling of the gingiva. Other applications which have been undertaken include gingivectomy, periodontal flap surgery, and the removal of granulation tissue.

Table 1: Details of handpieces and tips for oral surgery.

\begin{tabular}{|c|c|}
\hline Handpiece No & Applicators \\
\hline 2060 & Window non-contact handpiece \\
\hline 2061 & Rigid sapphire contact tips (various shapes) \\
\hline 2062 & Flexible optical fiber tips (various sizes) \\
\hline
\end{tabular}

A range of non-contact and contact applicators exist. The latter can be either rigid or flexible (Table 1). The non-contact window handpiece (No2060) is useful for mucosal resurfacing and for gingivoplasty, as there is a clear and unobstructed view of the target surface. Due to a lack of pressure, vibratory or thermal stimuli from the treatment site, most procedures are almost pain-free. A high water irrigant flow rate ensures overall cooling during surgery. For most procedures, there is no requirement 
for suturing, and so the need for local anaesthetic injections can often be eliminated. Such benefits reduce operating time and make procedures suitable for in-office delivery, particularly for young children and anxious adult patients.

The strong water absorption ensures that laser treated sites are rendered free of microbial contamination, providing good conditions for healing [16-20]. Using a non-contact handpiece, incisions as well as excisional procedures can be undertaken, including the removal of common oral lesions. The lased sites have a shallow zone of coagulation, and lased sites heal quickly with often little or no discomfort.

During procedures such as apicectomy and periodontal flap surgery where removal of residual microorganisms from the roots of teeth is critical, using a rigid contact sapphire tip and fluorescence guidance ensures that the endpoint of a clean site free of bacteria can be confirmed. Through its germicidal effects [21], Er:YAG laser energy can decontaminate any infected oral surface [22].

In summary, an Er:YAG laser with fluorescence feedback can provide for benefits for the operator (defined endpoints, shorter operating time) and for the patient (better outcomes). For dento-alveolar surgery and oral soft tissue procedures, this laser system can facilitate better patient outcomes from surgical interventions.

\section{References}

1. Schwarz F, Bieling K, Venghaus S, Sculean A, Jepsen S, et al. (2006) Influence of fluorescence-controlled Er:YAG laser radiation, the Vector system and hand instruments on periodontally diseased root surfaces in vivo. J Clin Periodontol 33(3): 200-208.

2. Shakibaie F, Walsh LJ (2015) Performance differences in the detection of subgingival calculus by laser fluorescence devices. Lasers Med Sci 30(9): 2281-2286.

3. Schwarz F, Sculean A, Berakdar M, Georg T, Reich E, et al. (2003) Clinical evaluation of an Er:YAG laser combined with scaling and root planing for non-surgical periodontal treatment. A controlled, prospective clinical study. J Clin Periodontol 30(1): 26-34.

4. Shakibaie F, Walsh LJ (2014) Surface area and volume determination of subgingival calculus using laser fluorescence. Lasers Med Sci 29(2): 519-524.

5. Shakibaie F, Walsh LJ (2015) DIAGNOdent Pen versus tactile sense for detection of subgingival calculus: an in vitro study. Clin Exp Dent Res 1(1): 26-31.

6. Lussi A, Megert B, Longbottom C, Reich E, Francescut P (2001) Clinical performance of a laser fluorescence device for detection of occlusal caries lesions. Eur J Oral Sci 109(1): 14-19.
7. Shakibaie F, Walsh LJ (2016) Laser fluorescence detection of subgingival calculus using the DIAGNOdent Classic versus periodontal probing. Lasers Med Sci 31(8): 1621-1626.

8. Shakibaie F, Walsh LJ (2012) Differential Reflectometry versus tactile sense detection of subgingival calculus in dentistry. J Biomed Opt 17(10): 106017.

9. Diniz MB, Boldieri T, Rodrigues JA, Santos-Pinto L, Lussi A, et al. (2012) The performance of conventional and fluorescence-based methods for occlusal caries detection:an in vivo study with histologic validation. J Am Dent Assoc 143(4): 339-350.

10. Shakibaie F, Walsh LJ (2016) Dental calculus detection using the VistaCam. Clin Exp Dent Res 2(3):226-229.

11. Shakibaie F, Walsh LJ (2017) Fluorescence imaging of dental restorations using the VistaCam intra-oral camera. Aust J Forensic Sci [in press] pp.1-9.

12. Shakibaie F, Walsh LJ (2015) Effect of oral fluids on dental caries detection by the VistaCam. Clin Exp Dent Res 1(2): 74-79.

13. Shakibaie F, Walsh LJ (2016) Violet and blue light-induced green fluorescence emissions from dental caries. Aust Dent J 61(4): 464-468.

14. Schwarz F, Sculean A, Georg T, Reich E (2001) Periodontal treatment with an Er: YAG laser compared to scaling and root planing. A controlled clinical study. J Periodontol 72(3): 361-367.

15. Shakibaie F, Diklic S, Walsh LJ (2002) An assessment of changes in dentine permeability following irradiation with a pulsed Erbium:YAG laser. Periodontology 23(1): 4-7.

16. Ishikawa I, Sasaki KM, Aoki A, Watanabe H (2003) Effects of Er:YAG laser on periodontal therapy. J Int Acad Periodontol 5(1): 23-28.

17. Crespi R, Barone A, Covani U (2006) Er:YAG laser scaling of diseased root surfaces: a histologic study. J Periodontol 77(2): 218-222.

18. Ha WN, Shakibaie F, Kahler B, Walsh LJ (2016) Deconvolution of the particle size distribution of ProRoot MTA and MTA Angelus. Acta Biomater Odontol Scand 2(1): 7-11.

19. Sculean A, Schwarz F, Berakdar M, Windisch P, Arweiler NB, et al. (2004) Healing of intrabony defects following surgical treatment with or without an Er:YAG laser. J Clin Periodontol 31(8): 604-608.

20. Stelzle F, Knipfer C, Bergauer B, Rohde M, Adler W, et al. (2014) Optical nerve identification in head and neck surgery after Er:YAG laser ablation. Lasers Med Sci 29(5): 1641-1648.

21. Bird PS, Shakibaie F, Gemmell E, Polak B, Seymour GJ (2001) Immune response to Bacteroides forsythus in a murine model. Oral Microbiol Immunol 16(5): 311-315.

22. Schwarz F, Bieling K, Nuesry E, Sculean A, Becker J (2006) Clinical and histological healing pattern of peri-implantitis lesions following non-surgical treatment with an Er:YAG laser. Lasers Surg Med 38(7): 663-671. 
This work is licensed under Creative Commons Attribution 4.0 Licens DOI: 10.19080/JHNSS.2017.01.555574

\section{Your next submission with Juniper Publishers will reach you the below assets}

- Quality Editorial service

- Swift Peer Review

- Reprints availability

- E-prints Service

- Manuscript Podcast for convenient understanding

- Global attainment for your research

- Manuscript accessibility in different formats

( Pdf, E-pub, Full Text, Audio)

- Unceasing customer service

Track the below URL for one-step submission https://juniperpublishers.com/online-submission.php 